\author{
Elżbieta Mitura \\ Lubelskie Centrum Edukacji Zawodowej \\ Danuta Jamroz \\ Zespół Szkół Włókienniczych w Lublinie
}

\title{
Przedsiębiorczy uczeń na rynku pracy
}

Zreformowana szkoła winna przygotowywać uczniów do podejmowania trudnych decyzji związanych z planowaniem przyszłej kariery i rozwoju zawodowego oraz do radzenia sobie w zmieniającej się rzeczywistości. Jednym z przedmiotów przygotowujących młodzież do aktywnego znalezienia się na rynku pracy jest przedsiębiorczość.

Dlaczego warto być przedsiębiorczym?

Nie jest łatwo jasno określić i precyzyjnie zdefiniować przedsiębiorczość. Można skorzystać z definicji encyklopedycznych, ale można też powiedzieć m.in., że przedsiębiorczość to aktywne i twórcze podejście człowieka do wyzwań przed nim stojących. To także postawa aktywnego poszukiwania.

Aktualna sytuacja rynkowa wymaga od człowieka przedsiębiorczych zachowań zmierzających do znalezienia swego miejsca i aktywnego w nim udziału. Niektóre osoby nie mają z tym większych problemów: wiedzą, co chcą w życiu osiągnąć i osiągają wyznaczony cel: zmierzając wyznaczoną drogą. Innym natomiast nic się nie udaje, boją się ryzyka, nie podejmują działań. Takim osobom powinno się uświadomić, że warto i należy być przedsiębiorczym.

Wszyscy, co jakiś czas powtarzamy, że młodzież jest zła, nieodpowiedzialna i leniwa i patrzymy jak coraz to nowe rzesze młodych ludzi zasilają szeregi bezrobotnych. W Unii Europejskiej od dawna kładziony jest nacisk na kształcenie wielorakich przydatnych w dorosłym życiu umiejętności. Badania pokazują, że jedną z cech, jaka powinna być kształtowana u młodych ludzi jest właśnie przedsiębiorczość, postawa, która jest przeciwieństwem bierności.

Jak zatem postępować, co robić, aby w młodych ludziach wykształcać przedsiębiorczość i wiarę we własne siły?

Celem kształcenia przedsiębiorczości jest właśnie przygotowanie uczniów do świadomego wyboru przyszłego kierunku kształcenia lub ścieżki kariery zawodowej w warunkach gospodarki rynkowej. Dlatego jak wcześniej wspomniano powinno się kłaść nacisk na to, by kształtować i rozwijać u uczniów intelektualne i praktyczne umiejętności niezbędne do poszukiwania i wykorzystywania informacji dotyczących:

- firmy,

- celów ich funkcjonowania,

- otoczenia współpracującego i konkurencyjnego,

- postaw podejmowania decyzji ekonomicznych,

- uruchamiania, planowania i organizacji działalności gospodarczej,

- zarządzania i strategii konkurowania firmy na rynku,

- zatrudnienia oraz samozatrudnienia. 
Przedmiot przygotowuje również ucznia do wejścia na rynek pracy poprzez kształtowanie takich umiejętności jak:

- przygotowanie odpowiedniej dokumentacji związanej z procesem poszukiwania i podejmowania pracy,

- prowadzenie rozmowy kwalifikacyjnej z potencjalnym pracodawcą,

- $\quad$ korzystanie z Kodeksu Pracy w interpretowaniu praw i obowiązków pracodawcy i pracobiorcy,

- $\quad$ korzystanie $\mathrm{z}$ instytucjonalnej pomocy państwa w przypadku trudności w znalezieniu pracy.

Należy więc podejmować różnorakie działania.

Chcemy zaprezentować jedną z podjętych przez nas inicjatyw, jaką jest zorganizowanie już 3-ech edycji wojewódzkiego konkursu „Przedsiębiorczy uczeń na rynku pracy”. Jest to konkurs realizowany jako projekt edukacyjny przez nauczycieli przedmiotów ekonomicznych i przedsiębiorczości (autorem pomysłu jest Elżbieta Mitura, jednym z współorganizatorów jest Danuta Jamroz).

Konkurs przeznaczony jest dla młodzieży szkół ogólnokształcących i nieekonomicznych zawodowych Lublina i województwa.

Przed przeprowadzeniem konkursu zostały zorganizowane warsztaty metodyczne dla nauczycieli.

Uczniowie mogli osiągnąc sukces, kiedy nauczyciele zwracali uwagę na kształtowanie u uczniów tzw. umiejętności kluczowych, do których można zaliczyć m.in.:

- umiejętność komunikowania się,

- umiejętność podejmowania decyzji,

- umiejętność organizowania i oceniania własnej pracy,

- umiejętność rozwiązywania problemów,

- umiejętność autoprezentacji.

\section{CELE I PRZEBIEG KONKURSU}

Konkurs przyczynia się do realizacji przez nauczycieli i uczniów celów krótko- i długofalowych.

Długofalowe cele konkursu to:

- wspieranie poprzez motywację procesu dydaktycznego przedsiębiorczości,

- poprawienie skuteczności nauczania w szkole.

Nauczyciele:

- $\quad$ wspierają w ramach konkursu autonomiczne uczenie się uczniów,

- kształtują u uczniów aktywne postawy wobec swojego życia osobistego i zawodowego,

- stosują metody aktywizujące,

- nawiązują współprace między sobą.

Uczniowie:

- nabywają umiejętności kluczowe niezbędne w ich dalszej karierze zawodowej,

- nabywają umiejętności kształtowania aktywnej postawy wobec swojego życia osobistego i zawodowego,

- $\quad$ wyrabiają umiejętności poznawania siebie i oceniania swoich możliwości psychofizycznych,

- rozwijają umiejętności niezbędne do skutecznego znalezienia pracy,

- posługują się właściwą terminologią.

W celach krótkofalowych:

Nauczyciel:

- będzie umiał przygotować ucznia do konkursu, 
- potrafi dostosować metody aktywizujące do odpowiednich tematów,

- będzie umiał dobrać różnorodne pomoce dydaktyczne,

- $\quad$ wymieni doświadczenie zawodowe z nauczycielami z innych szkół,

- będzie umiał ocenić korzyści wynikające z konkursu,

- traktuje ucznia jak partnera.

Uczeń:

- nabędzie umiejętności kluczowe niezbędne w jego dalszej karierze zawodowej,

- łatwiej będzie przyswajał wiedzę i nabywał nowe umiejętności,

- nabędzie umiejętności kontaktowania się i postępowania $\mathrm{z}$ innymi.

Tematyką konkursu była:

- gospodarka rynkowa,

- rynek pracy,

- poszukiwanie pracy,

- planowanie kariery zawodowej.

Konkursy przebiegały w 3 -ech etapach.

I etap to były eliminacje szkolne, które odbywały się jednocześnie we wszystkich, biorących udział w konkursie, szkołach. Polegał on na przeprowadzeniu testu w formie pisemnej.

II etap to były eliminacje międzyszkolne, które odbywały się w Lubelskim Centrum Edukacji Zawodowej.

III etap przebiegał również w ww. Centrum i polegał on na ustnej prezentacji przez ucznia wylosowanego tematu przed potencjalnym pracodawcą.

Patronat nad konkursem I i II edycji sprawował Miejski Urząd Pracy w Lublinie i Wyższa Szkoła Przedsiębiorczości i Administracji w Lublinie. Patronat nad III edycją sprawował Lubelski Kurator Oświaty, Rektor UMCS i wydawnictwo „Nowa Era”, które było także fundatorem głównej nagrody w konkursie. Poza tym sponsorami konkursu były lubelskie zakłady pracy, które były fundatorami nagród w postaci:

- zestawów komputerowych,

- 2 i 3-miesięcznych staży pracy,

- rocznych kursów języków obcych,

- kursów komputerowych,

- $\quad$ kursów kwalifikacyjnych (do wyboru w cenie 3000 zł),

- odzieży damskiej i męskiej,

- zegarków elektronicznych i kalkulatorów,

- albumów i książek.

Wszyscy finaliści otrzymali stosowne dyplomy, a nauczyciele podziękowania od $\mathrm{Ku}-$ ratora Oświaty.

W I konkursie udział wzięło 499 uczniów z 21 szkół. Do etapu II zakwalifikowało się 53 uczniów z 19 szkół, zaś do III etapu zakwalifikowało się 9 uczniów z 7 szkół.

W II edycji konkursu udział wzięło 534 uczniów z 27 szkół. Do II etapu zakwalifikowało się 62 uczniów z 23 szkół. Etap ten pozytywnie przeszło 12 uczniów z 9 szkół, którzy w III etapie prezentowali ustnie wylosowany temat.

Do I etapu III edycji konkursu przystąpiło 586 uczniów z 31 szkół, do etapu II zakwalifikowało się 105 uczniów z 25 szkół, zaś do etapu III zakwalifikowało się 15 uczniów z 12 szkół.

Zestawienie uczestników konkursów w poszczególnych edycjach i etapach obrazuje tabela 1 . 
Tabela 1. Zestawienie uczestników poszczególnych konkursów.

\begin{tabular}{|c|c|c|c|}
\cline { 2 - 4 } \multicolumn{1}{c|}{} & Edycja I & Edycja II & Edycja III \\
\hline Etap I & 499 & 534 & 586 \\
\hline Etap II & 53 & 62 & 105 \\
\hline Etap III & 9 & 12 & 15 \\
\hline
\end{tabular}

Wykres 1. Udział młodzieży $w$ poszczególnych edycjach i etapach konkursu: „Przedsiębiorczy uczeń na rynku pracy”.

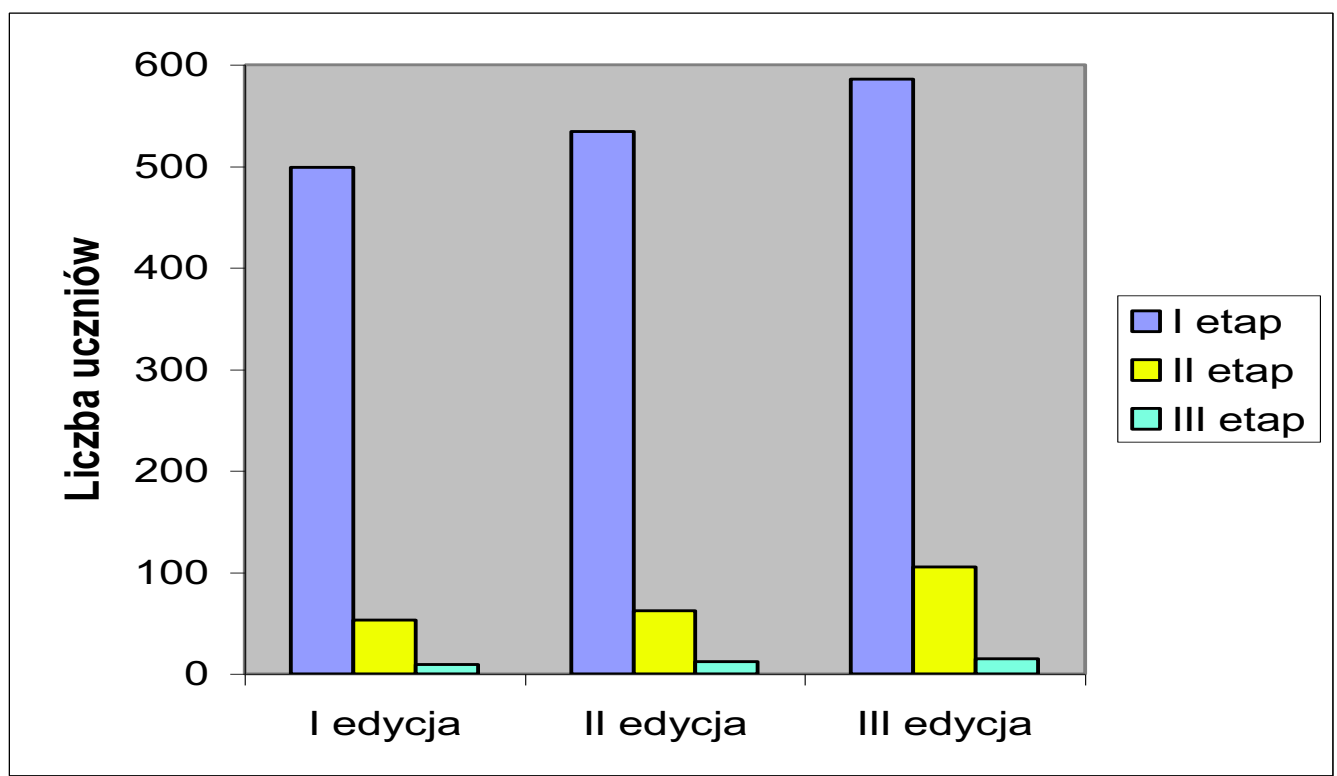

Z powyższego wykresu wynika, że konkurs cieszy się od samego początku ogromnym zainteresowaniem wśród młodzieży i wykazuje tendencję wzrostową.

\section{WYNIKI ANKIET PRZEPROWADZONYCH WŚRÓD MLODZIEŻY SZKÓŁ PONADGIMNAZJALNYCH MIASTA LUBLINA}

W celu potwierdzenia przydatności i celowości konkursu przeprowadziłyśmy badania ankietowe wśród uczniów z następujących typów szkół: liceum ogólnokształcące i profilowane, technika i szkoły zawodowe znajdujące się na terenie miasta Lublina.

Badania zostały przeprowadzone anonimowo. Wzięło w nich udział 326 uczniów, zarówno chłopcy jak i dziewczęta.

Poniższa tabela ilustruje udział młodzieży w badaniach ankietowych.

Tabela 2. Uczestnicy wg płci.

\begin{tabular}{|l|c|c|}
\hline \multirow{2}{*}{ Płeć } & \multicolumn{2}{|c|}{ Ogółem } \\
\cline { 2 - 3 } & Ilość osób & $\%$ \\
\hline Chłopcy & 207 & 63,5 \\
\hline Dziewczęta & 119 & 36,5 \\
\hline Razem & 326 & 100,0 \\
\hline
\end{tabular}


Wykres 2. Uczestnicy ankiety wg płci.

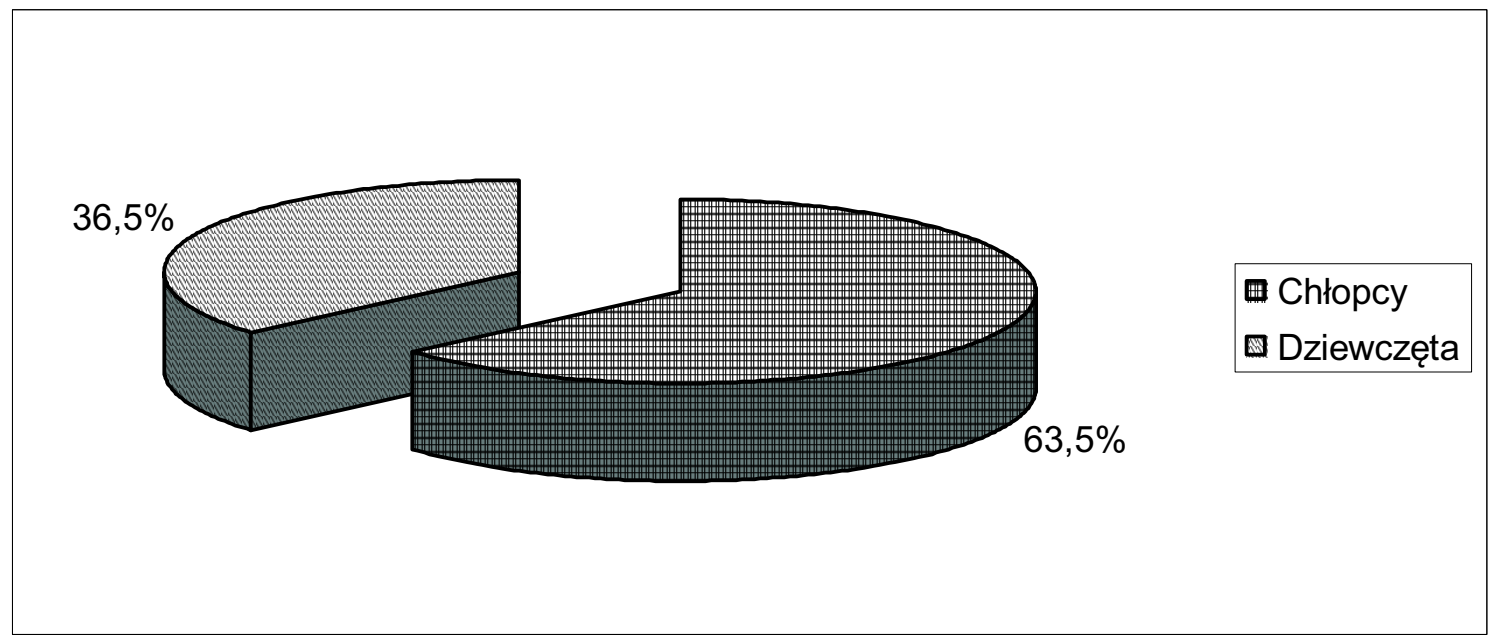

W badaniach uczestniczyło 326 uczniów, z czego dziewczęta stanowiły 36,5\% (119); chłopców było 207 (63,5\%).

Podstawowym pytaniem, na które szukałyśmy odpowiedzi była przydatność organizowania konkursu. Pokazuje to tabela nr 3.

Tabela 3. Przydatność konkursu.

\begin{tabular}{|l|c|c|c|c|}
\hline $\begin{array}{c}\text { Przydatność } \\
\text { konkursu }\end{array}$ & Chłopcy & Dziewczęta & Razem & $\%$ \\
\hline Tak & 165 & 93 & 258 & 79 \\
\hline Nie & 31 & 14 & 45 & 14 \\
\hline Nie mam zdania & 11 & 12 & 23 & 7 \\
\hline
\end{tabular}

Wykres 3. Przydatność organizowania konkursu.

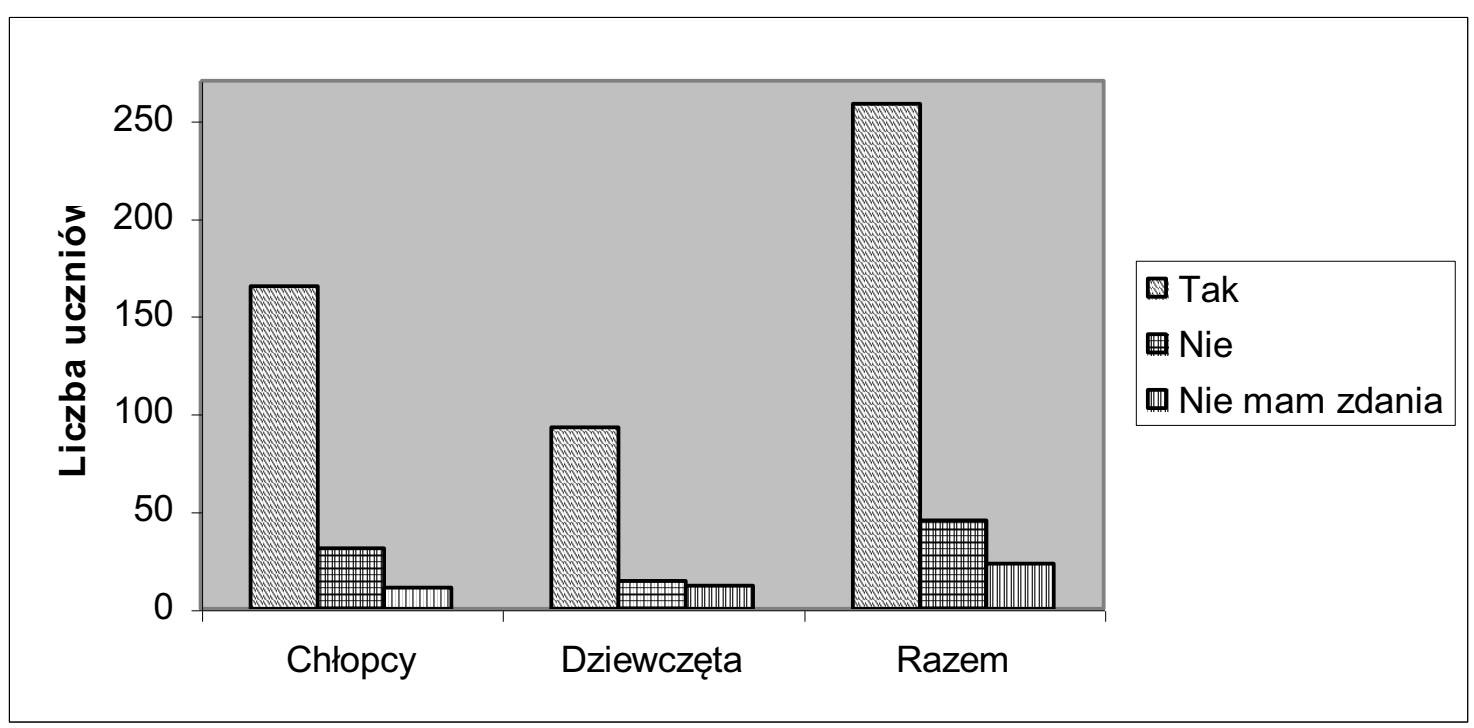

Wyniki pokazują, że zdecydowana większość młodzieży (258 osób tzn. 79\%) widzi potrzebę organizowania konkursu, tylko nieliczna grupa (68 osób tzn. 21\%) nie widzi takiej potrzeby lub nie ma zdania. 
Kolejna tabela ukazuje wyniki ankiety dotyczące stopnia zainteresowania uczniów lekcjami przedsiębiorczości.

Tabela 4. Zainteresowanie lekcjami przedsiębiorczości w szkole

\begin{tabular}{|l|c|c|}
\hline Zainteresowanie & Ogółem & $\%$ \\
\hline Bardzo mnie interesują & 28 & 8 \\
\hline Są interesujące & 140 & 43 \\
\hline Średnio mnie interesują & 111 & 34 \\
\hline Nie interesują mnie & 35 & 11 \\
\hline Nudzą mnie & 12 & 4 \\
\hline Razem & 326 & 100 \\
\hline
\end{tabular}

Wykres 4. Zainteresowanie lekcjami przedsiębiorczości w szkole.

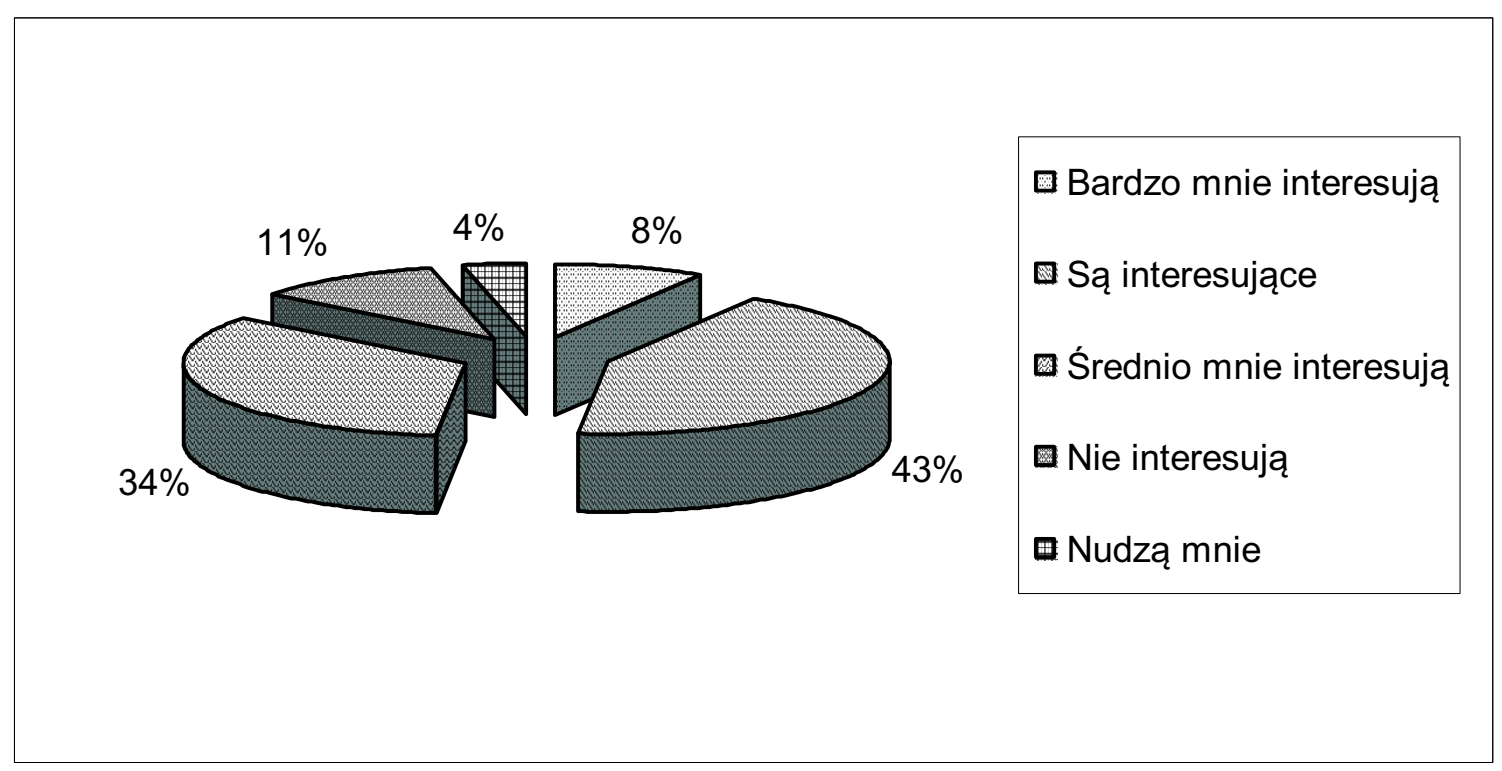

Wyniki wskazują, że niezbyt duża liczba uczniów jest mocno zainteresowana lekcjami przedsiębiorczości, ale tych znudzonych jest też niewiele. Zdecydowanie największa ilość uczniów jest średnio zainteresowana lekcjami, co wskazywałoby na konieczność dalszego ich uatrakcyjniania.

Kolejne pytanie ankiety dotyczyło podejmowanych działań przez nauczycieli w celu rozbudzania u uczniów postaw przedsiębiorczych.

Tabela 5. Rozbudzanie postaw przedsiębiorczych u uczniów

\begin{tabular}{|l|c|c|}
\hline Rodzaj działań & Ogółem & $\%$ \\
\hline Aktywność na lekcjach & 58 & 18 \\
\hline Udział w kole zainteresowań & 72 & 22 \\
\hline Tworzenie firmy szkolnej & 101 & 31 \\
\hline Udział w konkursach & 95 & 29 \\
\hline Razem & 326 & 100 \\
\hline
\end{tabular}

Badani są zainteresowani różnorodnymi formami rozbudzania własnej przedsiębiorczości, np. 101 respondentów chciałoby utworzyć i pracować w firmie szkolnej. Widzą w tym szansę na znalezienie własnej drogi życiowej, na lepszy start w dorosłość. 
Wykres 5. Rozbudzanie postaw przedsiębiorczych u uczniów

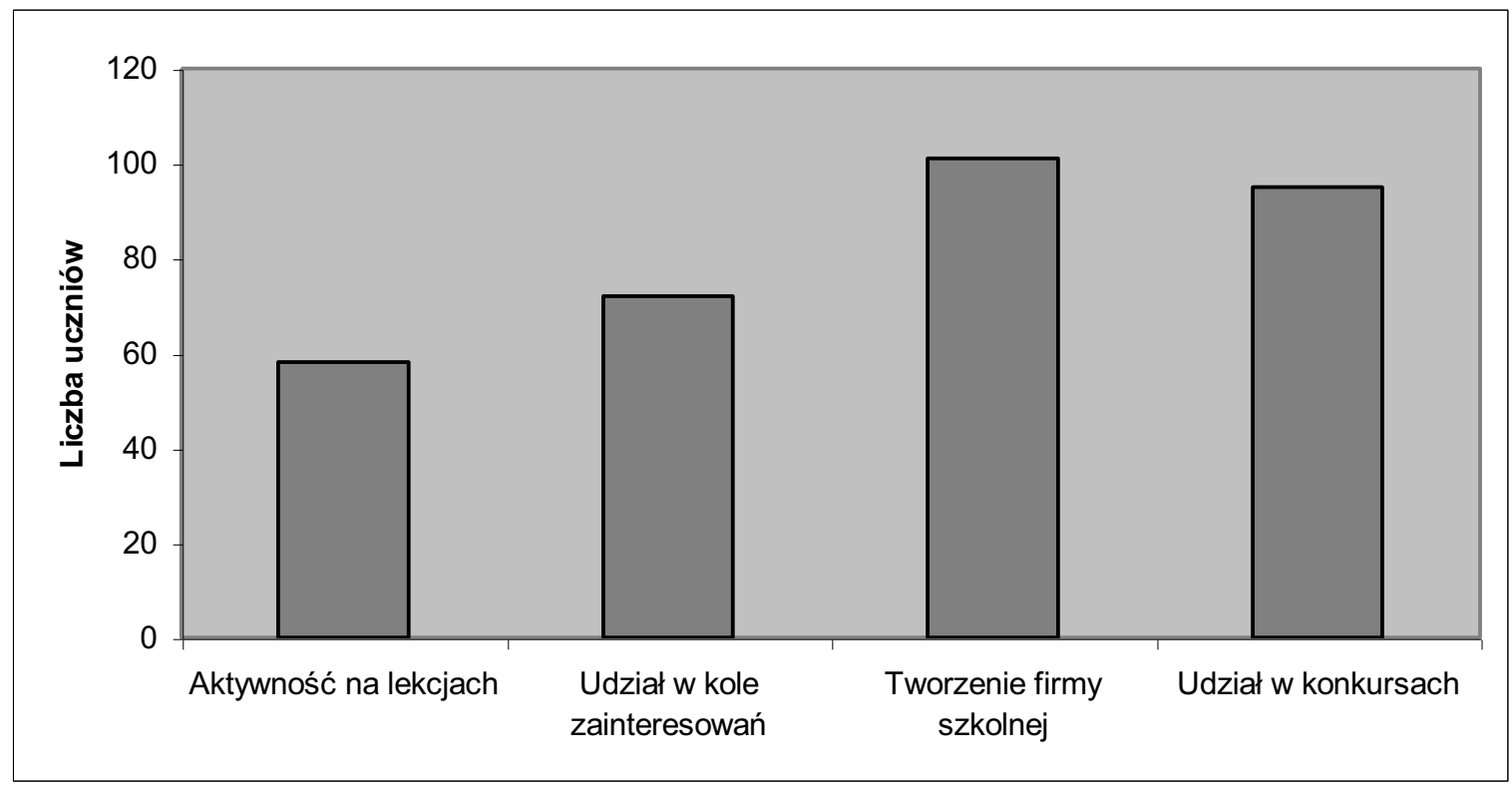

W kolejnym pytaniu dotyczącym samooceny własnej przedsiębiorczości uczniowie odpowiadają jak niżej:

Tabela 6. Samoocena własnej przedsiębiorczości

\begin{tabular}{|l|c|c|}
\hline $\begin{array}{l}\text { Samoocena własnej } \\
\text { przedsiębiorczości }\end{array}$ & Ogółem & $\%$ \\
\hline Bardzo dobra & 25 & 8 \\
\hline Dobra & 58 & 18 \\
\hline Przeciętna & 156 & 48 \\
\hline Słaba & 87 & 26 \\
\hline Razem & 326 & 100 \\
\hline
\end{tabular}

Wykres 6. Samoocena własnej przedsiębiorczości

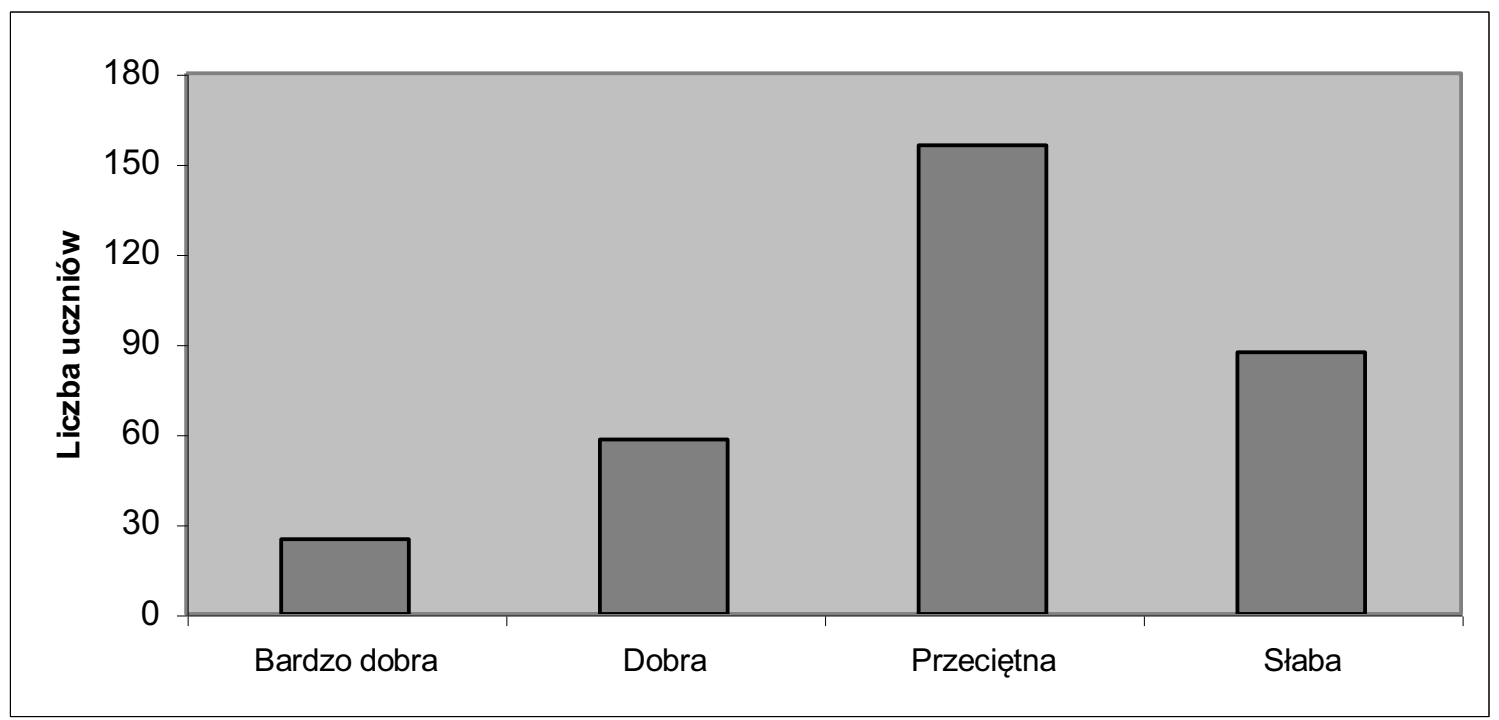


Zdecydowana większość młodzieży (156-48\%) ocenia siebie jako uczniów średnio i mało przedsiębiorczych (87-26\%) a niewielki procent uważa się za bardzo przedsiębiorczych (25-8\%). Wskazuje to na konieczność rozwijania postaw przedsiębiorczych wśród młodzieży szkolnej.

Ostatnie pytanie ankiety dotyczyło swobody wypowiedzi uczniów na forum klasy. Ilustruje to poniższa tabela.

Tabela 7. Częstotliwość swobodnej wypowiedzi uczniów w klasie

\begin{tabular}{|l|c|c|}
\hline Częstotliwość wypowiedzi & Ogółem & \% \\
\hline Często & 175 & 54 \\
\hline Rzadko & 130 & 40 \\
\hline Wcale & 21 & 6 \\
\hline Razem & 326 & 100 \\
\hline
\end{tabular}

Wykres 7. Częstotliwość swobodnej wypowiedzi uczniów w klasie

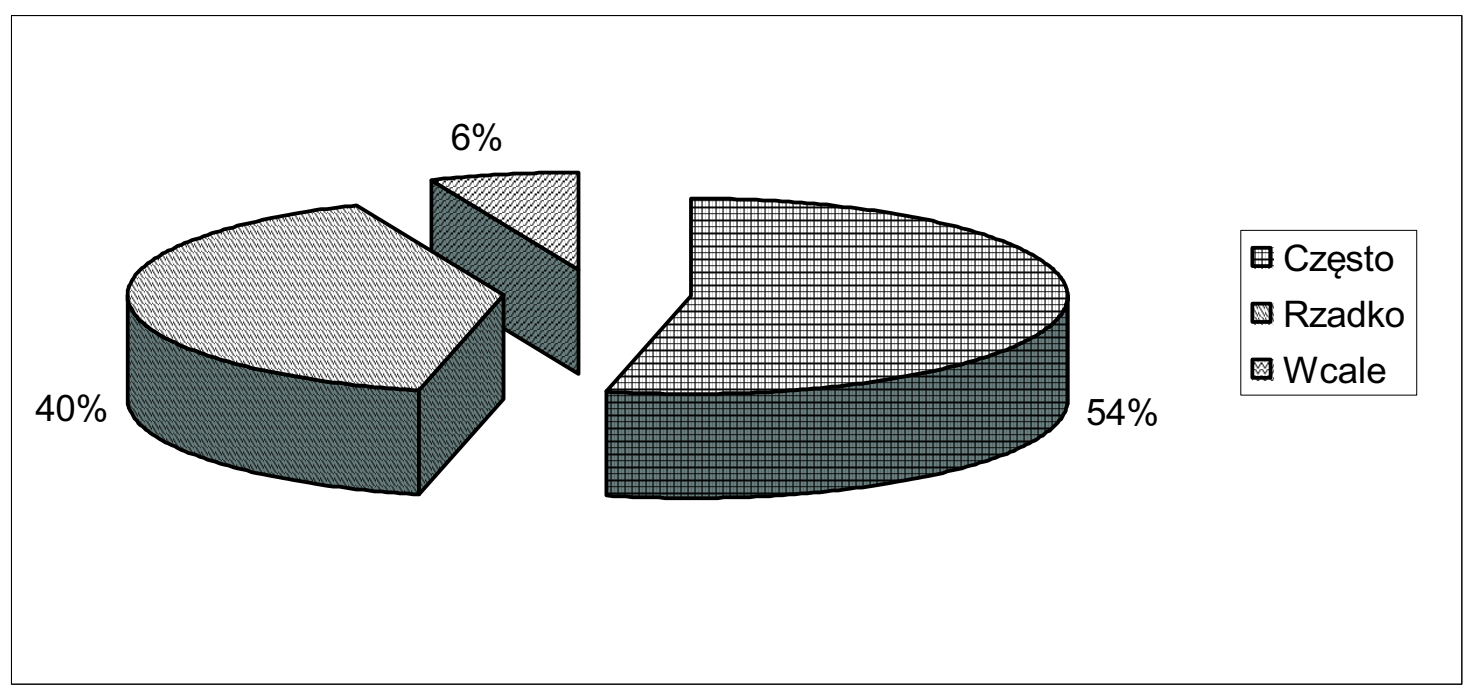

Przeważająca część młodzieży (54\%) uważa się za śmiałych, odważnych w klasie, niemających problemów ze swobodnym wypowiadaniem się. Jednak duża grupa uczniów $(46 \%)$ zabiera głos rzadko albo wcale z powodu lęku, strachu i niskiej samooceny.

\section{WNIOSKI Z PRZEPROWADZONYCH BADAŃ}

Z przeprowadzonych badań metodą ankietową wśród młodzieży szkół ponadgimnazjalnych wynikają wnioski, że w trakcie nauczania przedsiębiorczości należy przygotowywać młodzież do nowych warunków społeczno-gospodarczych i nowych wyzwań cywilizacyjnych a cywilizacyjnych, a w szczególności:

- uczyć samodzielności, aktywności, świadomego i trafnego podejmowania decyzji oraz ponoszenia ryzyka,

- kształtować umiejętność poruszania się na trudnym rynku pracy,

- $\quad$ kształcić umiejętność doskonalenia się i stosowania zdobytej wiedzy.

Realizacji powyższych wniosków służy organizowany przez nas konkurs: „Przedsiębiorczy uczeń na rynku pracy”. 


\section{LITERATURA}

Błasik A., Młodzież-świat wartości, WAM Kraków 2002.

Griffin. R. W., Podstawy zarzadzania organizacjami, Wyd. PWN 1999.

Hamer H., Rozwój przez wprowadzanie zmian, Centrum Edukacji Medycznej Warszawa 1999.

Ksztatcenie zawodowe, rynek pracy, pracodawcy, pod red. Stefana M. Kwiatkowskiego IBE 2000.

Podstawy marketingu, pod red. Henryka Mruka, Poznań 1999. 